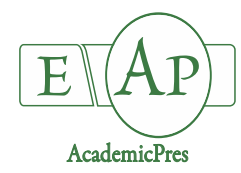

Karaca Oner E and Sonkaya M (2020)

Notulae Botanicae Horti Agrobotanici Cluj-Napoca 48(3):1185-1193

DOI: $10.15835 /$ nbha48311842

Research Article

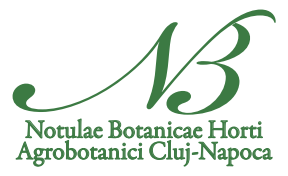

\title{
Identification of ontogenetic and diurnal variability in oregano (Origanum onites L.)
}

\author{
Emel KARACA ÖNER ${ }^{1 *}$, Merve SONKAYA ${ }^{2}$ \\ ${ }^{1}$ Ordu University, Technical Sciences Vocational School, Plant and Animal Production Department, 52200, Ordu, \\ Turkey; emelkaracaoner@odu.edu.tr (*corresponding author);emelkar55@hotmail.com \\ ${ }^{2}$ Ordu University, Institute of Science, 52200, Ordu, Turkey; mrvsonkaya@gmail.com
}

\begin{abstract}
Ontogenetic and diurnal variabilities in İzmir thyme (Origanum onites L.), an important essential oil and spice plant of Lamiaceae (Labiatae) family, were determined in this study. Experiments were conducted in randomized blocks - factorial experimental design with 3 replications. Two harvests were performed. Plants were harvested at different hours of a day (09:00, 13:00, 17:00) and in different growth periods (beginning of budding, beginning of flowering, $50 \%$ flowering and 100\% flowering). Plant height, fresh herbage yield, drug herbage yield, fresh leaf yield, drug leaf yield, essential oil ratio and essential oil yield parameters were investigated. High essential oil ratios were obtained from the plants harvested at morning hours. Essential oil ratios varied between $2.11-4.41 \%$. The greatest essential oil ratio was obtained from the plants harvested in morning hours of the beginning of budding period of the second harvests. Fresh herbage yields varied between $222.45-714.63 \mathrm{~kg} / \mathrm{da}$ with the greatest value from the plants harvested in the beginning of flowering period of the second harvests. Drug herbage yields varied between $64.30-256.74 \mathrm{~kg} / \mathrm{da}$ with the greatest value from the plants harvested in the beginning of flowering period of the second harvests.
\end{abstract}

Keywords: drug; essential oil; harvest hour; harvest period; oregano

\section{Introduction}

Thyme (Origanum, Thymus, Satureja, Thymbra, Coridothymus) is among the important medicinal and aromatic plants of Turkish flora. It belongs to Lamiaceae (Labiatae) family and is mostly used for essential oil and spice. There are several different species of thyme used as medicinal, aromatic and spice plant. Thyme essential oil is rich in carvacrol and thymol (Baydar, 2016). The oils sold under the brand of "thyme oil" are mostly obtained from Origanum species (Bağdat, 2011).

Mostly the leaves are used as spice, all above-ground parts of thymes are used as drug. Thyme leaves have essential oil contents of between $0.5-8.0 \%$. The thyme species to be used in essential oil industry should have at least $2.5 \%$ essential oil content. Thyme is mostly used as spice, less used as thyme tea, thyme oil or thyme juice. Since thyme contains essential oils with quite strong antimicrobial and antioxidant effects, it is used as a significant additive in foods, perfumes, cosmetics, drugs, lotions, soaps and toothpastes (Baydar et al., 2004; Özkan et al., 2010; Kapluhan, 2013). Thyme oil is used as antioxidant to prevent spoilage of foodstuffs, as insecticide (carvacrol) to prevent storage pests, as herbicide to prevent some weeds and as fumigant to prevent 
some diseases (Baydar, 2016). Turkey is the leading thyme exporter country of the world. Among the thyme species both collected from the nature and exported, Origanum onites L. is the most valuable one both economically and culturally (Okkalığlu et al., 2014; Baydar, 2016). Origanum onites L. is especially widespread in Mediterranean region of Turkey. The spread zone also includes Greece, Islands and South-West Anatolia. It naturally grows at altitudes of between $0-1400 \mathrm{~m}$. It is thermophilic plant and resistant to cold throughout the growing season, except for seedling stage and initial planting year. Thyme grows in almost every soil texture but grows better in clay-loam alluvial soils. Sandy soils are not good for thyme (Bayram, 2003).

Medicinal and aromatic plants have quite wide range of use and their significance and therapeutic characteristics are mostly designated by their active ingredients. Leaves, flowers, fruits and seeds of the plants are commonly used as drug and active ingredients of these sections of the plants generally vary with the growth seasons and changes in daily temperature and light intensity. Therefore, a drug producer should have a comprehensive knowledge about the changes in active ingredients and collect the plants from the proper places, at proper growth stages and dates when the plants were rich in drug-related active ingredients. By taking such changes into consideration, the most available organ, growth stage and harvest time for drug acquisition are decided. Previous studies revealed that the most appropriate harvest dates varied based on the plant species, climate and soil conditions of production sites (Aziz et al., 2013; Lakusic et al., 2013; Mammadov, 2014). In this study, effects of ontogenetic and diurnal variabilities on essential oil ratio and yield, drug and fresh herbage yield, drug and fresh leaf yield of oregano (Origanum onites L.) were investigated.

\section{Materials and Methods}

The seedlings produced from the Origanum onites L. seeds supplied from Aegean Agricultural Research Institute were used as the plant material of the present study.

Average temperatures of the experimental year $(2018)$ were about $2{ }^{\circ} \mathrm{C}$ above the long-term seasonal averages. Total precipitation was greater than long-term averages especially in July, but almost half of long-term averages in June and August.

Origanum onites L. seeds were germinated in peat-perlite filled pots in 2017 and resultant seedlings were transplanted into the field when they reached to a height of 8-10 cm. The year 2017 was considered as the experimental set up year and harvests were performed in 2018 vegetation period. Experiments were conducted in randomized blocks - factorial experimental design with 3 replications. Seedlings were planted at $40 \mathrm{~cm}$ row spacing and $20 \mathrm{~cm}$ on-row plant spacing $(40 \times 20 \mathrm{~cm})$. Harvests, observations and measurements were performed on two middle rows. Soil analyses were performed before the experiments and fertilization was practiced as to have $6 \mathrm{~kg} /$ da phosphorus $\left(\mathrm{P}_{2} \mathrm{O}_{5}\right)$ and $6 \mathrm{~kg} / \mathrm{da}$ nitrogen $(\mathrm{N})$ to meet macro element needs of the plants. Harvests were performed at 4 different periods (beginning of budding, beginning of flowering, 50\% flowering and 100\% flowering) and at 3 different hours of the day (9:00, 13:00 and 17:00). Two harvests (the first and the second) were performed in this study. Harvests were performed at all periods and hours in the first harvest, but harvests at $100 \%$ flowering period were not able to be made in the second harvest. Harvested samples were dried in a drying cabin at $35^{\circ} \mathrm{C}$ for 48 hours. Dried leaf samples $(40 \mathrm{~g})$ were placed into distillation flasks and supplemented with $1000 \mathrm{ml}$ water. Then the flasks were heated in heating mantles for 3 hours as not to exceed $120^{\circ} \mathrm{C}$. Following heating, distillation apparatus was cooled down for 5-10 minutes and essential oil quantity $(\mathrm{ml})$ collected over the water surface was measured from a graduated pipe (Telci et al., 2004; Yeşil, 2012). Experimental data were subjected to analysis of variance (ANOVA) with SAS-JMP. 13.0 statistical software. LSD multiple range test was used to compare significant means. 


\section{Results and Discussion}

\section{Plant height $(\mathrm{cm})$}

Effects of harvest periods on plant heights of Origanum onites were found to be significant in both harvests $(\mathrm{p}<0.01)$. There were significant differences also between the first and second harvests. In the first harvests, the greatest plat height obtained from the beginning of flowering period $(43.64 \mathrm{~cm})$ and the shortest plant height was obtained from the beginning of budding period $(36.33 \mathrm{~cm})$. In the second harvests, the greatest plant height was obtained from the beginning of flowering period $(29.43 \mathrm{~cm})$ and the shortest plant height was obtained from the $50 \%$ flowering period $(25.05 \mathrm{~cm})$. On the other hand, effects of harvest hours on plant heights were not found to be significant in both harvests. In both harvests, the greatest plant heights were obtained from the beginning of flowering period. In the beginning of flowering period, average plant height of the first harvests was about $32 \%$ greater than the average plant height of the 2 nd harvests (Table 1). Similar with the present findings for plant heights of oregano (Origanum onites L.) harvested at different periods, previous researchers also reported varying plant heights $(25.0-58.0 \mathrm{~cm})$ with harvest periods for different thyme species (Kızıl et al., 2010; Bahtiyarca Bağdat, 2011; Batıray and Kan, 2015, Özyazıcı and Kevseroğlu, 2019). Özyazıcı (2004) and Karık et al. (2007) reported significant effects of harvests on plant heights, but different from the present findings, they reported the greatest plants heights for $100 \%$ flowering period. Similar with the present findings, Kulan (2013) also indicated that harvest hours did not have any significant effects on plant heights.

Table 1. Effect of ontogenetics and diurnal variability on the plant length $(\mathrm{cm})$ of Origanum onites L. at I. and II. harvest

\begin{tabular}{|c|c|c|c|c|c|c|c|c|c|c|}
\hline \multicolumn{6}{|c|}{ First harvest } & \multicolumn{5}{|c|}{ Second harvest } \\
\hline Hour & Budding & $\begin{array}{c}\text { First } \\
\text { flowering }\end{array}$ & $\begin{array}{c}50 \% \\
\text { flowering }\end{array}$ & $\begin{array}{c}100 \% \\
\text { flowering }\end{array}$ & Mean & Budding & $\begin{array}{c}\text { First } \\
\text { flowering }\end{array}$ & $\begin{array}{c}50 \% \\
\text { flowering }\end{array}$ & $\begin{array}{c}100 \% \\
\text { flowering }\end{array}$ & Mean \\
\hline $9.00 \mathrm{am}$ & 35.83 & 45.07 & 43.33 & 39.23 & 40.86 & 27.80 & 28.40 & 23.46 & - & 26.55 \\
\hline $1.00 \mathrm{pm}$ & 36.30 & 43.23 & 39.10 & 38.60 & 39.30 & 28.20 & 29.53 & 25.70 & - & 27.81 \\
\hline $5.00 \mathrm{pm}$ & 36.86 & 42.63 & 42.00 & 42.93 & 41.11 & 27.40 & 30.36 & 26.00 & - & 27.92 \\
\hline Mean & $36.33 \mathrm{C}$ & $43.64 \mathrm{~A}^{* *}$ & $41.47 \mathrm{AB}$ & $40.25 \mathrm{~B}$ & & $27.80 \mathrm{~A}$ & $29.43 \mathrm{~A}^{*}$ & $25.05 \mathrm{~B}$ & - & \\
\hline \multicolumn{6}{|c|}{ LSD: 2.54} & \multicolumn{5}{|c|}{ LSD: 2.22} \\
\hline \multicolumn{11}{|c|}{${ }^{*}: \mathrm{P}<0.05^{* *}: \mathrm{P}<0.01$} \\
\hline
\end{tabular}

Fresh herbage yield ( $\mathrm{kg} / \mathrm{da})$

Effects of different harvest periods and hours on fresh herbage yields of Origanum onites were found to be significant in both harvests. Significant differences were also observed between the 1st and 2nd harvests. Considering the average fresh herbage yields of harvest periods, the greatest fresh herbage yield was obtained from $100 \%$ flowering period $(436.54 \mathrm{~kg} / \mathrm{da})$ in the first harvests and from the beginning of flowering period $(520.61 \mathrm{~kg} / \mathrm{da})$ in the second harvests. In the second harvests, the greatest fresh herbage yield was obtained from the plants harvested at 17:00. Considering the effects of ontogenetic and diurnal variabilities together, it was observed that the greatest fresh herbage yield was obtained from the second harvests made at 17:00 in the beginning of flowering period $(714.63 \mathrm{~kg} / \mathrm{da})$. The greatest fresh herbage yield of the first harvests was about $30 \%$ less than the greatest fresh herbage yield of the second harvests (Table 2). Similar with the present findings for the first harvests, Karık et al. (2007), Kızl (2009) and Özyazıcı (2004) reported the greatest fresh herbage yields for $100 \%$ flowering period. Güngör et al. (2005) reported greater fresh herbage yields of oregano for $50 \%$ flowering of the first harvests. Air temperature was high and dry conditions were dominant in the first harvests of the present study. Such high temperatures and dry conditions might have slowed down vegetative development and accelerated transition into flowering period. Therefore, fresh herbage yields of the first harvests were lower than the second harvests. 
Table 2. Effect of ontogenetics and diurnal variability on fresh herbage yield $(\mathrm{kg} / \mathrm{da})$ of Origanum onites

L. at I. and II. harvest

\begin{tabular}{|c|c|c|c|c|c|c|c|c|c|c|}
\hline \multicolumn{6}{|c|}{ First harvest } & \multicolumn{5}{|c|}{ Second harvest } \\
\hline Hour & Budding & $\begin{array}{c}\text { First } \\
\text { flowering }\end{array}$ & $\begin{array}{c}50 \% \\
\text { flowering }\end{array}$ & $\begin{array}{c}100 \% \\
\text { flowering }\end{array}$ & Mean & Budding & $\begin{array}{c}\text { First } \\
\text { flowering }\end{array}$ & $\begin{array}{c}50 \% \\
\text { flowering }\end{array}$ & $\begin{array}{c}100 \% \\
\text { flowering }\end{array}$ & Mean \\
\hline $\begin{array}{c}9.00 \\
\mathrm{am}\end{array}$ & $255.88 \mathrm{e}$ & $254.42 \mathrm{e}$ & $341.96 \mathrm{~cd}$ & $496.65 \mathrm{a}^{* *}$ & $\begin{array}{c}337.23 \\
\text { B }\end{array}$ & $355.39 \mathrm{~cd}$ & $327.04 \mathrm{~d}$ & $398.41 \mathrm{~cd}$ & - & $\begin{array}{c}360.28 \\
\text { C }\end{array}$ \\
\hline $\begin{array}{c}1.00 \\
\mathrm{pm}\end{array}$ & $222.45 \mathrm{e}$ & $378.78 \mathrm{bc}$ & $246.94 \mathrm{e}$ & $487.58 \mathrm{a}$ & $\begin{array}{c}333.94 \\
\text { B }\end{array}$ & $349.15 \mathrm{~cd}$ & $520.17 \mathrm{~b}$ & $418.09 \mathrm{~cd}$ & - & $\begin{array}{c}429.14 \\
\text { B }\end{array}$ \\
\hline $\begin{array}{c}5.00 \\
\mathrm{pm}\end{array}$ & $251.25 \mathrm{e}$ & $482.66 \mathrm{a}$ & $385.58 \mathrm{~b}$ & $325.38 \mathrm{~d}$ & $\begin{array}{c}361.22 \\
\mathrm{~A}^{*}\end{array}$ & $373.56 \mathrm{~cd}$ & $714.63 \mathrm{a}^{*}$ & $436.36 \mathrm{bc}$ & - & $\begin{array}{c}508.18 \\
\mathrm{~A}^{*}\end{array}$ \\
\hline Mean & $243.19 \mathrm{D}$ & $371.95 \mathrm{~B}$ & $324.82 \mathrm{C}$ & $436.54 \mathrm{~A}^{* *}$ & & $359.37 \mathrm{C}$ & $520.61 \mathrm{~A}^{*}$ & $417.62 \mathrm{~B}$ & - & \\
\hline \multicolumn{6}{|c|}{ LSD (Period): 23.34; LSD (Hour): 20.21; LSD (PXH): 40.43} & \multicolumn{5}{|c|}{ LSD (Period): 54.03; LSD (Hour): 54.03; LSD (PXH): 93.58} \\
\hline \multicolumn{11}{|c|}{${ }^{*}: \mathrm{P}<0.05^{* *}: \mathrm{P}<0.01$} \\
\hline
\end{tabular}

Drug herbage yield ( $\mathrm{kg} / \mathrm{da})$

In the first harvests, different harvest periods alone and together with harvest hours and significant effects on drug herbage yields of Origanum onites. In the second harvests, harvest periods and hours alone and together had significant effects on drug herbage yields. There were significant differences also between the first and the second harvests. With regard to average drug herbage yields of different periods, the greatest drug herbage yield was obtained from the beginning of flowering period of the second harvests $(175.92 \mathrm{~kg} / \mathrm{da}$ ). Such a value was $6 \%$ greater than the greatest value of the first harvests. Harvest hours were found to be significant in the second harvests and the greatest drug herbage yield was obtained from the plants harvested at 17:00 $(186.32 \mathrm{~kg} / \mathrm{da})$. Considering the together effects of harvest periods and hours, the greatest drug herbage yield was obtained from 9:00 of 100\% flowering period in the first harvests $(186.49 \mathrm{~kg} / \mathrm{da}$ ) and from 17:00 of the beginning of flowering period in the second harvests $(256.74 \mathrm{~kg} / \mathrm{da}$ ) (Table 3$)$. The average drug herbage yield of the second harvests was about $37 \%$ greater than the average drug herbage yield of the second harvest. Güngör (2002) conducted a study on İzmir thymes with harvests and reported greater drug herbage yields than the present values.

Table 3. Effect of ontogenetics and diurnal variability on drug herbage yield $(\mathrm{kg} / \mathrm{da})$ of Origanum onites L. at I. and II. harvest

\begin{tabular}{|c|c|c|c|c|c|c|c|c|c|c|}
\hline \multicolumn{6}{|c|}{ First harvest } & \multicolumn{5}{|c|}{ Second harvest } \\
\hline Hour & Budding & $\begin{array}{c}\text { First } \\
\text { flowering }\end{array}$ & $\begin{array}{c}50 \% \\
\text { flowering }\end{array}$ & $\begin{array}{c}100 \% \\
\text { flowering }\end{array}$ & Mean & Budding & $\begin{array}{c}\text { First } \\
\text { flowering }\end{array}$ & $\begin{array}{c}50 \% \\
\text { flowering }\end{array}$ & $\begin{array}{c}100 \% \\
\text { flowering }\end{array}$ & Mean \\
\hline $\begin{array}{c}9.00 \\
\mathrm{am}\end{array}$ & $87.41 \mathrm{~d}$ & $64.30 \mathrm{e}$ & $110.92 \mathrm{c}$ & $186.49 a^{* *}$ & 112.28 & $112.39 \mathrm{bc}$ & $107.43 \mathrm{c}$ & $122.84 \mathrm{bc}$ & - & $114.22 \mathrm{~B}$ \\
\hline $\begin{array}{l}1.00 \\
\mathrm{pm}\end{array}$ & $74.23 \mathrm{de}$ & $108.64 \mathrm{c}$ & $80.49 \mathrm{de}$ & $185.21 \mathrm{a}$ & 112.14 & $111.15 \mathrm{c}$ & $163.61 \mathrm{~b}$ & $139.81 \mathrm{bc}$ & - & $138.19 \mathrm{~B}$ \\
\hline $\begin{array}{l}5.00 \\
\mathrm{pm}\end{array}$ & $82.62 \mathrm{~d}$ & $134.58 \mathrm{~b}$ & $124.34 \mathrm{bc}$ & $123.10 \mathrm{dc}$ & 116.16 & $147.06 \mathrm{bc}$ & $256.74 \mathrm{a}^{*}$ & $155.16 \mathrm{bc}$ & - & $186.32 \mathrm{~A}^{*}$ \\
\hline Mean & $81.42 \mathrm{C}$ & $102.50 \mathrm{~B}$ & $105.25 \mathrm{~B}$ & $164.93 \mathrm{~A}^{* *}$ & & $123.53 \mathrm{~B}$ & $175.92 \mathrm{~A}^{*}$ & $139.27 \mathrm{~B}$ & - & \\
\hline \multicolumn{6}{|c|}{ LSD (Period): 10.36 LSD (PXH): 17.95} & \multicolumn{5}{|c|}{ LSD (Period): 29.63; LSD (Hour): 29.63; LSD (PXH): 51.32} \\
\hline \multicolumn{11}{|c|}{${ }^{*}: \mathrm{P}<0.05,{ }^{* *}: \mathrm{P}<0.01$} \\
\hline
\end{tabular}

\section{Fresh leaf yield $(\mathrm{kg} / \mathrm{da})$}

Effects of ontogenetic and diurnal variabilities on fresh leaf yields of Origanum onites L. were found to be significant in both harvests. Considering the fresh leaf yields of different harvest period, the greatest fresh leaf yield was obtained from $100 \%$ flowering period $(297.87 \mathrm{~kg} / \mathrm{da})$ in the first harvests. Considering the different harvest hours, the greatest fresh leaf yield was obtained from the harvests made at 17:00 (255.83 $\mathrm{kg} / \mathrm{da}$ ). Considering the effects of harvest periods and hours together, the greatest fresh herbage yield of the first harvests was obtained from harvests made at 13:00 of $100 \%$ flowering period $(347.82 \mathrm{~kg} / \mathrm{da})$ and the lowest fresh leaf yield was obtained from the harvests made at 13:00 of the beginning of budding period (124.61 $\mathrm{kg} / \mathrm{da}$ ). In the second harvests, the greatest fresh leaf yield was obtained from the beginning of flowering period 
$(327.23 \mathrm{~kg} / \mathrm{da})$ and from the harvests made at $17: 00(351.42 \mathrm{~kg} / \mathrm{da})$. Considering the together effects of ontogenetic and diurnal variability, the greatest fresh leaf yield was obtained from the harvests made at 17:00 of the beginning of flowering period $(482.05 \mathrm{~kg} / \mathrm{da})$ and the lowest fresh leaf yield was obtained from the harvests made at 13:00 of the beginning of budding period (213.16 kg/da) (Table 4). Kirman (1993) (in flowering period) and Bahtiyarca Bağdat (2011) reported greater fresh leaf yields in the second harvests than in the first harvests. Similar with the findings of previous studies, the greatest fresh leaf yields in both harvests were obtained from the harvests made in flowering period.

Table 4. Effect of ontogenetics and diurnal variability on fresh leaf yield (kg/da) of Origanum onites L. at I. and II. harvest

\begin{tabular}{|c|c|c|c|c|c|c|c|c|c|c|}
\hline \multicolumn{6}{|c|}{ First harvest } & \multicolumn{5}{|c|}{ Second harvest } \\
\hline Hour & Budding & $\begin{array}{c}\text { First } \\
\text { flowering }\end{array}$ & $\begin{array}{c}50 \% \\
\text { flowering }\end{array}$ & $\begin{array}{c}100 \% \\
\text { flowering }\end{array}$ & Mean & Budding & $\begin{array}{c}\text { First } \\
\text { flowering }\end{array}$ & $\begin{array}{c}50 \% \\
\text { flowering }\end{array}$ & $\begin{array}{c}100 \% \\
\text { flowering }\end{array}$ & Mean \\
\hline $\begin{array}{l}9.00 \\
\mathrm{am}\end{array}$ & $143.90 \mathrm{~h} ı$ & $173.09 \mathrm{fg}$ & $239.44 \mathrm{e}$ & $324.27 \mathrm{~b}$ & $\begin{array}{c}220.18 \\
\text { B }\end{array}$ & $230.40 \mathrm{~b}$ & $222.65 \mathrm{~b}$ & $266.06 \mathrm{~b}$ & - & $\begin{array}{c}239.70 \\
\text { B }\end{array}$ \\
\hline $\begin{array}{l}1.00 \\
\mathrm{pm}\end{array}$ & 124.611 & $263.92 \mathrm{~d}$ & $176.49 \mathrm{f}$ & $347.82 \mathrm{a}^{* *}$ & $\begin{array}{c}228.21 \\
\text { B }\end{array}$ & $213.16 \mathrm{~b}$ & $276.99 \mathrm{~b}$ & $283.16 \mathrm{~b}$ & - & $\begin{array}{c}257.77 \\
\text { B }\end{array}$ \\
\hline $\begin{array}{l}5.00 \\
\mathrm{pm}\end{array}$ & $152.16 \mathrm{gh}$ & $358.69 \mathrm{a}$ & $290.96 \mathrm{c}$ & $221.52 \mathrm{e}$ & $\begin{array}{c}255.83 \\
\mathrm{~A}^{* *}\end{array}$ & $267.16 b$ & $482.05 \mathrm{a}^{*}$ & $305.06 \mathrm{~b}$ & - & $\begin{array}{c}351.42 \\
\mathrm{~A}^{*}\end{array}$ \\
\hline Mean & $140.22 \mathrm{D}$ & $265.24 \mathrm{~B}$ & $235.63 \mathrm{C}$ & $297.87 \mathrm{~A}^{* *}$ & & $236.90 \mathrm{~B}$ & $327.23 \mathrm{~A}^{*}$ & $284.76 \mathrm{AB}$ & - & \\
\hline \multicolumn{6}{|c|}{ LSD (Period): 12.59; LSD (Hour): 10.91; LSD (PXH): 21.82} & \multicolumn{5}{|c|}{ LSD (Period): 56.56; LSD (Hour): 56.56; LSD (PXH): 97.96} \\
\hline \multicolumn{11}{|c|}{${ }^{*}: \mathrm{P}<0.05^{* *}: \mathrm{P}<0.01$} \\
\hline
\end{tabular}

\section{Drugleaf yield ( $\mathrm{kg} / \mathrm{da})$}

Effects of ontogenetic and diurnal variability of drug leaf yield of Origanum onites L. were found to be significant in both harvests. In the first harvest, the greatest drug leaf yield was obtained from 1005 flowering period $(162.84 \mathrm{~kg} / \mathrm{da})$ and the lowest drug leaf yield was obtained from the beginning of budding period $(89.74$ $\mathrm{kg} / \mathrm{da}$ ). Considering the together effects of harvest periods and hours in the first harvests, the greatest drug leaf yield was obtained from the harvests made at 9:00 of $100 \%$ flowering period $(207.78 \mathrm{~kg} / \mathrm{da})$. In the second harvests, the greatest drug leaf yield was obtained from the beginning of flowering period $(209.25 \mathrm{~kg} / \mathrm{da})$ and the lowest drug leaf yield was obtained from the beginning of budding period $(124.49 \mathrm{~kg} / \mathrm{da})$. Effects of diurnal variability alone was not found to be significant in the first harvests, but significant in the second harvests. Drug leaf yields of the second harvest varied between $180.15 \mathrm{~kg} / \mathrm{da}(17: 00)-119.02 \mathrm{~kg} / \mathrm{da}(9: 00)$. Considering the effects of variabilities together in the second harvests, the greatest drug herbage yield was obtained from the harvests made at 13:00 of the beginning of flowering period $(260.00 \mathrm{~kg} / \mathrm{da})$ and the lowest from the harvests made at 9:00 of the beginning of flowering period $(110.70 \mathrm{~kg} / \mathrm{da}$ ) (Table 5). Yalçıntaş Özyazıcı (2004) reported the greatest drug leaf yield of Origanum onites L. in the first and second harvests for the harvests made in 100\% flowering period. Those findings comply with the present findings for the first harvest, but not with the findings for the second harvests.

\section{Essential oil ratio (\%)}

Effects of harvest periods on essential oil ratios were found to be significant in both harvests and effects of harvest hours were found to be significant only in the second harvests. The greatest essential oil ratio was obtained from the beginning of budding period of the second harvest (4.41\%). Such a value was $27 \%$ greater than the greatest value of the second harvests in $100 \%$ flowering period. Essential oil ratios at different hours of the second harvests varied between 4.36\% (9:00) - 3.71\% (13:00). Considering the effects of harvest period $\mathrm{x}$ harvest hour interactions, the greatest essential oil ratio was obtained from the harvests made at 9:00 of the beginning of budding period (4.82\%) and the lowest from the harvests made at 13:00 of 50\% flowering period (3.22\%) (Table 6). Plant essential oil ratios generally vary based on climate, environmental and topographic conditions and morphogenetic, ontogenetic and diurnal variability (Arabacı et al., 2012). In present study, high essential oil ratios were achieved in harvests made at morning hours of flowering periods. It was reported in 
previous studies conducted in Turkey with Origanum onites and the other thyme species that essential oil ratios varied with the harvest periods and hours. Similar with the present findings, greater essential oil ratios were generally observed in the second harvests (Yalçıntaş Özyazıc1, 2004; Kaçar et al., 2006; Avcı and Bayram, 2006). Sağlam (2005) reported the greatest essential oil ratio (1.58\%) for morning hours of $50 \%$ flowering period; Yaldiz et al. (2005) reported the greatest essential oil ratio (1.62\%) for post-flowering period; Kizll et al. (2009) reported the greatest essential ratio (3.65\%) for afternoon hours of full flowering period. Arabac1 et al. (2012) investigated the effects of diurnal variability on Coridothymus capitatus (L.) genotypes and reported the greatest essential oil ratio for full flowering period. Such findings support the differences observed in this study with ontogenetic and diurnal variability. Kaya et al. (2013) harvested Thymus vulgaris L. plants in onehour intervals between the hours 06:00 - 17:00 and reported the greatest essential ratio $(2.20 \%)$ for the harvests made at 06:00 and indicated that essential oil ratios decreased within the day. Similar with the findings of those studies, the greatest essential oil ratio of the present study was also obtained from the harvests made at morning hours.

Table 5. Effect of ontogenetics and diurnal variability on drug leaf yield $(\mathrm{kg} / \mathrm{da})$ of Origanum onites $\mathrm{L}$. at I. and II. harvest

\begin{tabular}{|c|c|c|c|c|c|c|c|c|c|c|}
\hline \multicolumn{6}{|c|}{ First harvest } & \multicolumn{5}{|c|}{ Second harvest } \\
\hline Hour & Budding & $\begin{array}{c}\text { First } \\
\text { flowering }\end{array}$ & $\begin{array}{c}50 \% \\
\text { flowering }\end{array}$ & $\begin{array}{c}100 \% \\
\text { flowering }\end{array}$ & Mean & Budding & $\begin{array}{c}\text { First } \\
\text { flowering }\end{array}$ & $\begin{array}{c}50 \% \\
\text { flowering }\end{array}$ & $\begin{array}{c}100 \% \\
\text { flowering }\end{array}$ & Mean \\
\hline $\begin{array}{c}9.00 \\
\text { am }\end{array}$ & 93.71 cde & $72.90 \mathrm{e}$ & $117.14 \mathrm{bc}$ & $207.78 a^{* *}$ & 122.88 & $119.02 \mathrm{~b}$ & $110.70 \mathrm{~b}$ & $127.35 \mathrm{~b}$ & - & $119.02 \mathrm{~B}$ \\
\hline $\begin{array}{l}1.00 \\
\mathrm{pm}\end{array}$ & $83.76 \mathrm{de}$ & $\begin{array}{c}115.18 \\
\text { bcd }\end{array}$ & $137.94 \mathrm{~b}$ & $188.15 \mathrm{a}$ & 131.26 & $126.81 \mathrm{~b}$ & $260.00 \mathrm{a}^{*}$ & $122.96 \mathrm{~b}$ & - & $169.93 \mathrm{~A}$ \\
\hline $\begin{array}{l}5.00 \\
\mathrm{pm}\end{array}$ & 91.76 cde & $140.82 \mathrm{~b}$ & $137.64 \mathrm{~b}$ & $92.61 \mathrm{cde}$ & 115.71 & $127.63 \mathrm{~b}$ & $257.04 \mathrm{a}$ & $155.77 \mathrm{~b}$ & - & $180.15 \mathrm{~A}^{*}$ \\
\hline Mean & $89.74 \mathrm{D}$ & $109.63 \mathrm{C}$ & $130.90 \mathrm{~B}$ & $162.84 \mathrm{~A}^{* *}$ & & $124.49 \mathrm{~B}$ & $209.25 \mathrm{~A}^{* *}$ & $135.36 \mathrm{~B}$ & - & \\
\hline \multicolumn{6}{|c|}{ LSD (Period): 18.83; LSD (PXH): 32.62} & \multicolumn{5}{|c|}{ LSD (Period): 30.98; LSD (Hour): 30.98; LSD (PXH): 53.65} \\
\hline \multicolumn{11}{|c|}{${ }^{*}: \mathrm{P}<0.05,{ }^{* *}: \mathrm{P}<0.01$} \\
\hline
\end{tabular}

Table 6. Effect of ontogenetics and diurnal variability on essential oil ratio (\%) $(\mathrm{kg} / \mathrm{da})$ of Origanum onites L. at I. and II. harvest

\begin{tabular}{|c|c|c|c|c|c|c|c|c|c|c|}
\hline \multicolumn{6}{|c|}{ First harvest } & \multicolumn{5}{|c|}{ Second harvest } \\
\hline Hour & Budding & $\begin{array}{c}\text { First } \\
\text { flowering }\end{array}$ & $\begin{array}{c}50 \% \\
\text { flowering }\end{array}$ & $\begin{array}{c}100 \% \\
\text { flowering }\end{array}$ & Mean & Budding & $\begin{array}{c}\text { First } \\
\text { flowering }\end{array}$ & $\begin{array}{c}50 \% \\
\text { flowering }\end{array}$ & $\begin{array}{c}100 \% \\
\text { flowering }\end{array}$ & Mean \\
\hline $9.00 \mathrm{am}$ & 2.33 & 3.37 & 2.90 & 3.50 & 3.03 & 4.82 & 4.25 & 4.00 & - & $4.36 \mathrm{~A}^{* *}$ \\
\hline $1.00 \mathrm{pm}$ & 2.16 & 3.40 & 2.56 & 3.55 & 2.92 & 4.19 & 3.72 & 3.22 & - & $3.71 \mathrm{C}$ \\
\hline $5.00 \mathrm{pm}$ & 1.83 & 3.26 & 2.77 & 3.37 & 2.81 & 4.22 & 3.85 & 3.83 & - & $3.97 \mathrm{~B}$ \\
\hline Mean & $2.11 \mathrm{C}$ & $3.34 \mathrm{~A}$ & $2.75 \mathrm{~B}$ & $3.47 \mathrm{~A}^{* *}$ & & $4.41 \mathrm{~A}^{* *}$ & $3.94 \mathrm{~B}$ & $3.68 \mathrm{C}$ & - & \\
\hline \multicolumn{5}{|c|}{ LSD (Period): 0.27} & \multicolumn{6}{|c|}{ LSD (Period): $0.22 ;$ LSD (Hour): 0.22} \\
\hline & & & & & $15 *$ & & & & & \\
\hline
\end{tabular}

\section{Essential oil yield (1/da)}

Different harvest periods and hours had significant effects on essential oil yields of Origanum onites L. in both harvests. In the first harvests of Origanum onites L., the greatest essential oil yield was obtained from the $100 \%$ flowering period $(5.67 \mathrm{l} / \mathrm{da})$ and the lowest from the beginning of budding period $(1.88 \mathrm{l} / \mathrm{da})$. Essential oil yields of different harvest hours varied between 4.16 1/da (13:00) - 3.29 1/da (17:00). Considering the together effects of ontogenetic and diurnal variability on essential oil yields of the first harvests, the greatest value was obtained from the harvests made at 9:00 of 100\% flowering period $(7.26 \mathrm{l} / \mathrm{da})$ and the lowest from the harvests made at 17:00 of the beginning of budding period $(1.67 \mathrm{l} / \mathrm{da})$. In the second harvests of Origanum onites L., the greatest essential oil yield was obtained from the beginning of flowering period $(8.08 \mathrm{l} / \mathrm{da})$ and the lowest from the $50 \%$ flowering period $(4.99 \mathrm{l} / \mathrm{da}$ ). Considering the effects of diurnal variability, the greatest essential oil yield was obtained from the harvests made at 17:00 (7.08 $1 / \mathrm{da})$ and the lowest from the harvests made at 9:00 (5.19 1/da). Considering the effects of variabilities together, the greatest essential oil yield was 
obtained from the harvests made at 17:00 of the beginning of flowering period $(9.93 \mathrm{l} / \mathrm{da})$ and the lowest from the plants harvested at 9:00 of the beginning of flowering period (4.72 l/da) (Table 7). Essential oil ratio and essential oil yield based on drug leaf yield vary with the plant genetics, ecological conditions of growing sites (Özyazıcı and Kevseroğlu, 2019). In previous studies on oregano (Origanum onites L.), Güngör (2002) and Baydar (2002) reported decreasing essential oil yields after the first harvest. Contrarily, greater essential oil yields were obtained from the second harvests in present study.

Table 7. Effect of ontogenetics and diurnal variability on essential oil yield (\%) (kg/da) of Origanum onites L. at I. and II. harvest

\begin{tabular}{|c|c|c|c|c|c|c|c|c|c|c|}
\hline \multicolumn{9}{|c|}{ First harvest } & \multicolumn{5}{c|}{ Second harvest } \\
\hline Hour & Budding & $\begin{array}{c}\text { First } \\
\text { flowering }\end{array}$ & $\begin{array}{c}50 \% \\
\text { flowering }\end{array}$ & $\begin{array}{c}100 \% \\
\text { flowering }\end{array}$ & Mean & Budding & $\begin{array}{c}\text { First } \\
\text { flowering }\end{array}$ & $\begin{array}{c}50 \% \\
\text { flowering }\end{array}$ & $\begin{array}{c}100 \% \\
\text { flowering }\end{array}$ & Mean \\
\hline $9.00 \mathrm{am}$ & $2.16 \mathrm{def}$ & $2.43 \mathrm{def}$ & $3.41 \mathrm{bcd}$ & $7.26 \mathrm{a}^{* *}$ & $3.81 \mathrm{AB}$ & $5.76 \mathrm{~b}$ & $4.72 \mathrm{~b}$ & $5.08 \mathrm{~b}$ & - & $5.19 \mathrm{~B}$ \\
\hline $1.00 \mathrm{pm}$ & $1.80 \mathrm{ef}$ & $3.92 \mathrm{bc}$ & $4.22 \mathrm{bc}$ & $6.69 \mathrm{a}$ & $4.16 \mathrm{~A}^{*}$ & $5.34 \mathrm{~b}$ & $9.58 \mathrm{a}$ & $3.95 \mathrm{~b}$ & - & $6.29 \mathrm{AB}$ \\
\hline $5.00 \mathrm{pm}$ & $1.67 \mathrm{f}$ & $4.60 \mathrm{~b}$ & $3.82 \mathrm{bc}$ & $3.07 \mathrm{cde}$ & $3.29 \mathrm{~B}$ & $5.36 \mathrm{~b}$ & $9.93 \mathrm{a}^{*}$ & $5.94 \mathrm{~b}$ & - & $7.08 \mathrm{~A}^{*}$ \\
\hline Mean & $1.88 \mathrm{C}$ & $3.65 \mathrm{~B}$ & $3.81 \mathrm{~B}$ & $5.67 \mathrm{~A}^{* *}$ & & $5.49 \mathrm{~B}$ & $8.08 \mathrm{~A}^{* *}$ & $4.99 \mathrm{~B}$ & - & \\
\hline \multicolumn{10}{|c|}{ LSD (Period): 0.78; LSD (Hour): $0.67 ; \mathrm{LSD}(\mathrm{PXH}): 1.34$} \\
\hline \multicolumn{10}{|c|}{$<0.05,{ }^{* *}: \mathrm{P}<0.01$} \\
\hline
\end{tabular}

\section{Conclusions}

Active substances in the parts of plants used as drog vary depending on the development periods of the plant and the changes in temperature and light during the day. When these changes are taken into account, it is important to decide which part of the plant, which stage of development and when it is best to obtain the drog. Significant ecological factors (soil, water, climate, etc.) influence the yield of drog and the ratio of essential oil. Essential oils of oregano are used for various purposes. For this reason, Herba yield and essential oil ratio in thyme cultivation are among the most important parameters to focus on. Finally, greater fresh herbage yields, drug herbage yields, fresh leaf yields, drug leaf yields and essential oil ratios, which are important parameters for oregano production, were obtained from the plants harvested in the beginning of flowering and 100\% flowering periods. With regard to harvest hours, the greatest fresh herbage yield, drug herbage yield, fresh leaf yield and drug herbage yield were obtained from the plants harvested at late afternoon hours and the greatest essential oil ratios were obtained from the plants harvested at morning hours.

\section{Authors' Contributions}

Both authors read and approved the final manuscript.

\section{Acknowledgements}

This research received no specific grant from any funding agency in the public, commercial, or not-forprofit sectors.

\section{Conflict of Interests}

The authors declare that there are no conflicts of interest related to this article. 


\section{References}

Arabacı O, Öğretmen NG, Aslan DF, Özcan İI (2012). Ontogenetic variability in Coridothymus capitatus L. genotypes. Medicine and Aromatic Plants Symposium, 13-15 September 2012, Tokat, Proceedings Book, pp 88.

Avc1 B, Bayram E (2006). Determination of some agronomic and technologic characteristics of improved Turkish oregano (Origanum onites L.) clones under different ecological conditions. Institute of Science, Ph.D. Thesis, İzmir, pp 153.

Aziz EE, Sabry RM, Ahmed SS (2013). Plant growth and essential oil production of sage (Salvia officinalis L.) and curlyleafed parsley (Petroselinum crispum ssp. crispum L.) cultivated under salt stress conditions. World Applied Sciences Journal 28(6):785-796. https://doi.org/10.5829/idosi.wasj.2013.28.06.13846

Bagdat BR (2011). Comparision of the yield and quality parameters of certain species which are used as "ekekik" in Turkey. Ankara University, Institute of Science, Field Crops Department, Ph.D. Thesis.

Batıray S, Kan Y (2015). Konya ekolojik şartlarında yetiştirilen İzmir Kekiğinde (Origanum onites L.) farklı dozlarda uygulanan azot ve organik gübrelerin verim ve kalite özellikleri üzerine etkisi. Selçuk Tarım ve Gıda Bilimleri Dergisi 27(1):8-13. http://hdl.handle.net/123456789/7600

Baydar H (2016). Medicinal and aromatic plants science and technology book (Extended 5 th Edition). Suleyman Demirel University Faculty of Agriculture, Publication No: 51. Isparta.

Baydar H, Sagdiç O, Özkan G, Karadoğan T (2004). Antibacterial activity and composition of essential oils from Origanum, Thymbra and Satureja species with commercial importance in Turkey. Food Control 15(3):169-172. https://doi.org/10.1016/S0956-7135(03)00028-8

Baydar H (2002). Research on yield and essential oil quality of Izmir thyme (Origanum onites L.) under Isparta conditions. Süleyman Demirel University Journal of the Institute of Science 6(2):15-21.

Güngör F U (2002). Comparison of clones developed in Izmir thyme (Origanum onites L.) in terms of quality and agronomic. Ankara University, Institute of Science, Field Crops Department. PhD thesis.

Güngör FU, Bayraktar N, Kaya MD (2005). Comparison of improved Izmir thyme (Origanum onites L.) clones in terms of agriculture and quality in Kula conditions. Journal of Agricultural Sciences 11(2):196-200.

Kaçar O, Göksu E, Azkan N (2006). The effect of different plant densities on some agronomic and quality characteristics of oregano (Origanum onites L.). Uludağ University Journal of Faculty of Agriculture 20(2):51-60.

Kapluhan E (2013). An example of alternative agricultural activities in Bekilli (Denizli): thyme growing. Marmara Geography Journal (28):194-210.

Karık Ü, Tinmaz AB, Kürkçüoğlu M, Başer KHC, Tümen G (2007). Effect of dıfferent cuttıng tıme on yıeld and qualıty in İstanbul Kekiği (Origanum vulgare L. subsp. hirtum) populatıons. Garden 36(1):37-48.

Kaya DA, Arslan M, Rusu LC (2013). Effects of harvesting hour on essential oil content and composition of Thymus vulgaris. Farmacia 61(6):1194-1203.

Kirman H (1993). Research on the determination of some agronomic and quality properties of the improved Izmir thyme (Origanum onites L.) lines. EU Faculty of Agriculture. Master's Thesis.

Kizıl S (2009). The effect of different harvest stages on some agronomical characteristics of lemon balm (Melissa officinalis L.). Tarim Bilimleri Dergisi 15(1):20-24.

Kızıl S, İpek A, Arslan N, Khawar KM (2009). Some agronomical characteristics and essential oil content of oregano (Origanum onites L.) as influenced by planting densities. Journal of Essential Oil Bearing Plants 12(2):172-180. https://doi.org/10.1080/0972060X.2009.10643707

Kızıl S, İpek A, Arslan N, Khawar KM (2010). Effect of different developing stages on some agronomical characteristics and essential oil composition of oregano (Origanum onites). New Zealand Journal of Crop and Horticultural Science 36:71-76.

Kulan EG (2013). Determination of some plant characteristics and diurnal variability of basil (Ocimum basilicum L.) grown under eskişehir conditions. ESOGU Department of Field Crops. Master of Science Thesıs.

Lakusic BS, Ristic MS, Slavkovska VN, Stojanovic DL, Lakusic DV (2013). Variations in essential oil yields and compositions of Salvia officinalis (Lamiaceae) at different developmental stages. Botanica Serbica 37(2):127-139.

Mammadov R (2014). Tohumlu Bitkilerde Sekonder Metabolitler. Nobel Akademik Yayıncılık, Ankara.

Okkaoglu H, Sonmez Ç, Sİmsek O, Bayram E (2014). Cultivation of Istanbul thyme (Origanum vulgare var. Hirtum) under Karaisalı conditions. 1th Field Crops Congress. 7-10 September 2015, Çanakkale, Volume 2, pp 704-708. 
Özkan G, Baydar H, Erbas S (2010). The influence of harvest time on essential oil composition, phenolic constituents and antioxidant properties of Turkish oregano (Origanum onites L.). Journal of the Science of Food and Agriculture 90(2):205-209. https://doi.org/10.1002/jsfa.3788

Özyazıcı G, Kevseroğlu K (2019). Effects of ontogenetic variability on yield of some Labiatae family (Mentha spicata L., Origanum onites L., Melissa officinalis L., Lavandula angustifolia Mill.) plants. Turkish Journal Agriculture Research 6(2):174-185. https://doi.org/10.19159/tutad.510877

Sağlam B (2005). The effect of organic fertilizer and ontogenetic and diurnal variability on yield and important quality characteristics of some plants belonging to Labiatae family (Origanum onites L., Melissa officinalis L., Thymus praecox). Ondokuz Mayıs University Institute of Science Field Crops Department. Master's Thesis.

Telci I, Sahbaz NI, Yilmaz G, Tugay ME (2004). Agronomical and chemical characterization of spearmint (Mentha spicata L.) originating in Turkey. Economic Botany 58(4):721. https://doi.org/10.1663/00130001(2004)058[0721:AACCOS]2.0.CO;2

Yalçıntas OG (2004). Effects of ontogenetic variability on yield and some quality parameters of some Labiatae family (Mentha spicata L., Origanum onites L., Melissa officinalis L., Lavandula angustifolia Mill.) plants. Ondokuz Mayıs University Field Crops Department, Ph.D. Thesis.

Yaldız G, Sekeroglu N, Özgüven M, Kirpik M (2005). Seasonal and diurnal variability of essential oil and its components in Origanum onites L. grown in the ecological conditions of Cukurova. Grasas y Aceites 56(4):254-258. https://doi.org/10.3989/gya.2005.v56.i4.89

Yeşil M (2012). Effect of different nitrogen and phosphorus doses on some essential oil components of Mentha spicata L. and Mentha villoso-nervata L. genotypes. Atatürk University, Institute of Science, Field Crops Department, Ph.D. Thesis.
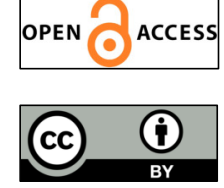

The journal offers free, immediate, and unrestricted access to peer-reviewed research and scholarly work. Users are allowed to read, download, copy, distribute, print, search, or link to the full texts of the articles, or use them for any other lawful purpose, without asking prior permission from the publisher or the author.

License - Articles published in Notulae Botanicae Horti Agrobotanici Cluj-Napoca are Open-Access, distributed under the terms and conditions of the Creative Commons Attribution (CC BY 4.0) License.

(c) Articles by the authors; UASVM, Cluj-Napoca, Romania. The journal allows the author(s) to hold the copyright/to retain publishing rights without restriction. 